\title{
South Africa names head of science ministry
}

Michael Cherry, Cape Town

An applied mathematician has been appointed minister of science and technology in the new South African government - and has pledged to start bringing more young people into science.

Since apartheid collapsed ten years ago, the average age of South Africa's scientific workforce has gone up, with few young researchers being recruited. The country's share of global published scientific output fell from $0.8 \%$ in 1990 to $0.5 \%$ in 2000 (A. Pouris S. Afr. J. Sci. 99, 425-427; 2003).

But the new minister, 56-year-old Mosibudi Mangena, who holds a master's degree from the University of South Africa, has said he will confront the problem. "To redress this situation, we urgently need to identify talent and nurture it," he said shortly after his appointment on 29 April.

Mangena, a former political prisoner and exile, is the head of a tiny minority left-wing party, the Azanian People's Organisation, which secured only one seat in parliament in the recent elections. He was previously deputy minister of education. But because he is not a member of President Thabo Mbeki's African National Congress, which dominates the new government, some scientists fear that Mangena will have a tough job making his voice heard.

He says that his main task will be to persuade the cabinet to reverse the past decade's $30 \%$ decline in South African spending, as a proportion of the economy, on research and development. This has recently increased slightly, from $0.69 \%$ in $1997-98$ to $0.76 \%$ in $2001-02$, but it is still far from the target of $1 \%$ by next year that was set out in a national research strategy published in 2002.

Mangena says he is confident that the government will see the wisdom of increasing research spending, despite other pressing demands for social services. "The president has already committed the government to a higher profile for science and technology," he says. "Once we have committed more funds, we shall have to find ways of persuading the private sector to follow suit."

But the biggest problem facing the new minister is to attract more young people into science, which is widely viewed as arcane and poorly paid. Only 4,800 black pupils achieved a higher-grade pass in mathematics in the school-leaving examinations last year, and science courses were the least popular at universities.

The apartheid government, "for all its faults, provided resources for research", concedes Mangena. As a consequence, most of the country's research base is concentrated in its science councils and in a few historically predominantly white universities. "I don't think that it is feasible for all the country's universities to be doing top-level research," he says, "but it is essential that research institutions change radically, and do not remain a white preserve."

Khotso Mokhele, president of the National Research Foundation, the country's main grant funding agency, says he was "delighted" with Mangena's appointment because of his qualifications as an applied mathematician and also his understanding of the problems facing researchers.

Fritz Hahne, director of the African Institute for Mathematical Sciences in Cape Town, also welcomed Mangena's appointment "on account of his strong track record of support for science, and mathematics in particular".

\section{Researchers fear break-up of UK medical institute}

Laura Nelson, London

Scientists at the National Institute for Medical Research (NIMR) at Mill Hill in north London are worried that their institute could soon be split up.

The Medical Research Council (MRC) has confirmed that it is revisiting a previous decision to keep the NIMR - one of Britain's premier centres for basic medical research on one site.

The MRC has been trying to shift the emphasis of the institute more towards clinical research, and last year suggested that the site should be moved closer to a research hospital, proposing Addenbrooke's Hospital in Cambridge (see Nature 423, 573; 2003).

After protests by the institute's researchers, a task force decided in March this year that the institute would not move to Cambridge, but would instead stay put or move to a different, single site in London. It rejected another proposal that the institute be broken into pieces to be closer to hospitals around London.

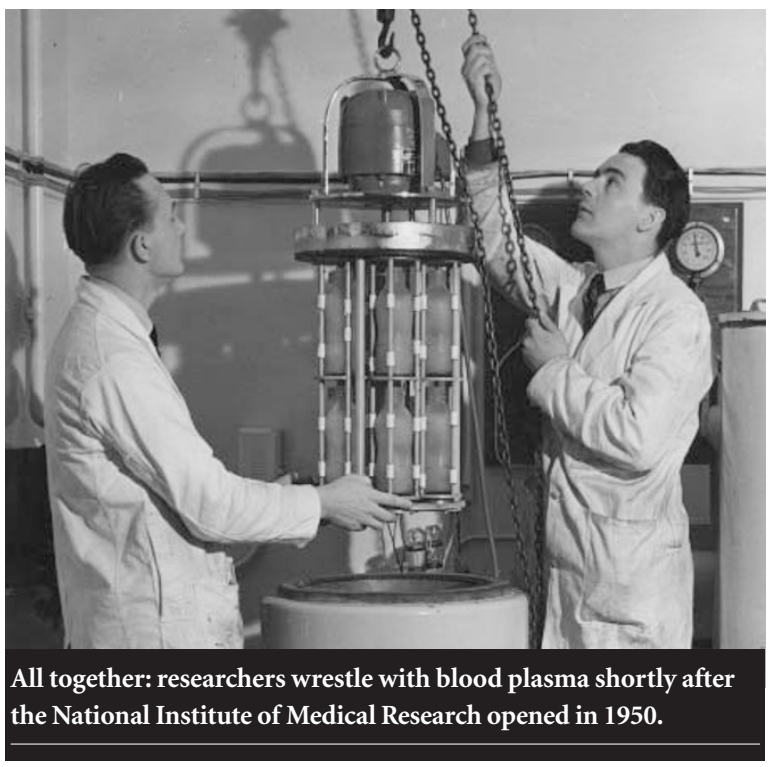

The task force has since consulted London hospitals and colleges that could potentially offer sites to the new NIMR. "We asked what they could do and they have offered a variety of proposals," says Colin Blakemore, chief executive of the MRC and chairman of the task force reviewing the institute's fate. "We would like to keep the NIMR as one institute. But there are practical constraints," he says. "We have to look at more modest possibilities."

Some of the roughly 600 NIMR scientists, students and staff are now convinced that their institute is destined to be split into pieces around London. "The idea of them finding a single site is unlikely," says Barrie Brown, head of labour

But last month the task force had a change of heart. In response to an MRCcommissioned study on investment requirements, carried out by consultancy company Ove Arup and Partners, it reinstated the option of "an institute located on more than one site". relations for Amicus MSF, one of the NIMR's trade unions. "Our priority is to retain a single-site institute, because we think it is a driving force for medical research," says Brown.

The task force aims to present a London site proposal to the MRC in July. 